\title{
TINGKAT KEPUASAN MEMBERS TERHADAP STRATEGI PEMASARAN DI LEMBAH FITNESS CENTRE UNIVERSITAS GAJAH MADA
}

\author{
Rina Yuniana ${ }^{1}$, Ahmad Nasrulloh ${ }^{1}$ \\ ${ }^{1}$ Fakultas Ilmu Keolahragaan, Universitas Negeri Yogyakarta. Colombo No. 1, Karangmalang Depok, Sleman, \\ Yogyakarta, Indonesia. \\ rinayuniana@uny.ac.id, ahmadnasrulloh@uny.ac.id
}

\begin{abstract}
Abstrak
Lembah Fitness Centre UGM juga perlu melakukan pengelolaan dan menerapkan strategi pemasaran yang baik agar members dapat merasakan kepuasan. Penelitian ini bertujuan untuk mengetahui tingkat kepuasan members terhadap strategi pemasaran di Lembah Fitness Centre Universitas Gajah Mada. Populasi dalam penelitian ini adalah members Lembah Fitness Centre UGM yang aktif mengikuti latihan beban sebanyak 240 orang. Teknik pengambilan sampel yang digunakan dalam penelitian ini yaitu dengan metode nonprobability sampling menggunakan teknik accidental sampling, sebanyak 120 orang. Instrumen yang digunakan adalah angket atau kuesioner. Angket tersebut diujicobakan terhadap 40 members Lembah Fitness Centre UGM. Hasil ujicoba menunjukkan dari 48 butir pernyataan gugur 3 butir, sahih 45 butir. Teknik untuk mengukur validitas menggunakan teknik korelasi product moment dari Karl Pearson dengan taraf signifikasi $5 \%$ atau $\alpha=0,05$. Butir pernyataan dikatakan valid apabila nilai korelasi dari product moment (rxy) lebih besar dari r-tabel. Nilai koefisien alpha (rtt) yang diperoleh sebesar 0,912 dengan status reliabel. Teknik analisis data penelitian menggunakan analisis deskriptif kuantitatif dengan persentase. Hasil penelitian ini menunjukkan bahwa secara umum tingkat kepuasan members masuk ke dalam kategori memuaskan dengan pencapaian persentase $60,8 \%$. Secara rinci, tingkat kepuasan members terhadap strategi pemasaran di Lembah Fitness Centre UGM dijelaskan sebagai berikut: (1) Price atau harga masuk kedalam kategori sangat memuaskan dengan persentase $60 \%$, (2) Promotion atau promosi masuk kedalam kategori memuaskan dengan persentase $55 \%$, (3) Place atau tempat masuk kedalam kategori memuaskan dengan persentase 49,2 \%, (4) Product atau produk/jasa masuk kedalam kategori memuaskan dengan persentase sebesar 55,8\%.
\end{abstract}

Kata kunci: manajemen, kepuasan, strategi pemasaran

\section{MEMBERS SATISFACTION LEVEL TOWARD MARKETING STRATEGY IN LEMBAH FITNESS CENTER UNIVERSITAS NEGERI GAJAH MADA}

\begin{abstract}
Fitness center companies must manage fitness club well. In process, club must be applied marketing strategy, same as Lembah Fitness Center UGM where need to be manage and use marketing streategy so that members satisfied with their services. This study aims to know about level of satisfaction members toward marketing strategy in Lembah Fitness center Universitas Negeri Gajah Mada. Participants in this study are members of Lembah Fitness Center UGM that enganged actively in resistance training for almost 240 people. Sampling technique using nonprobability method include accidental sampling method, 120 people. Questionnaire used as instrument in this study. This questionnaire being trial into 40 members,
\end{abstract}


then the result showed only 45 questions from 48 which have validity based on product moment correlation technique (Karl Pearson) with significance level $\alpha=0,05$. Validity of each question attained if its have correlation value from product moment (rxy) more than r-tabel. Data analysis using quantitative descriptive analysis with precentage. The results of this study indicate that the level of satisfaction members toward marketing strategy at the UGM Fitness Center resulted in satisfactory category with a percentage of $60.8 \%$. In detail, the level of satisfaction of members of the marketing strategy at the Lembah Fitness Center UGM is through the following factors: (1) Price belong to very satisfying category with a percentage of $60 \%$, (2) Promotion percentage reach $55 \%$, (3) Place percentage is $49.2 \%$, and (4) Product achieve $55.8 \%$.

Keywords: Management, satisfaction, marketing strategy

\section{PENDAHULUAN}

Di era globalisasi ini, berbagai macam aktivitas yang dilakukan manusia sangat padat dan beraneka ragam. Hal tersebut akan menuntut manusia untuk memiliki tubuh yang tetap sehat dan bugar, tetapi saat ini kebugaran menjadi suatu fenomena yang membuat orang bertanya-tanya, sebenarnya apa arti dari kebugaran. Seberapa besar pengaruhnya terhadap aktivitas dan bagaimana cara untuk memperoleh kebugaran tersebut. Dari fenomena di atas dapat diambil kesimpulan bahwa semakin banyak orang yang tertarik akan arti pentingnya kebugaran, karena kebugaran fisik (physical fitness) merupakan kemampuan seseorang untuk melakukan kerja sehari-hari secara efisien tanpa timbul kelelahan yang berlebihan, sehingga masih dapat menikmati waktu luangnya (Djoko, 2004: 2). Saat ini, orang-orang sibuk menginginkan untuk mengisi dan memanfaatkan waktu luangnya dengan berolahraga. Mereka bisa mendapatkan semua itu dengan mendatangi pusat-pusat kebugaran, karena dengan berolahraga di pusat kebugaran, mereka dapat berolahraga tanpa merasa kepanasan dan alat-alat yang disediakan cukup banyak dan memadai. Hal tersebut dapat menimbulkan permintaan akan adanya pusat kebugaran yang cukup tinggi, sehingga mengakibatkan pangsa pasar yang tinggi pula.

Pangsa pasar yang tinggi ini akan menjadi alasan dasar bagi para pengusaha pusat kebugaran (fitness centre) untuk berlomba-lomba terjun dalam bidang usaha ini. Usaha yang mereka lakukan dijadikan suatu bisnis dalam memperoleh keuntungan yang sebanyak-banyaknya, sehingga mengakibatkan menjamurnya pusat-pusat kebugaran, terutama di kota-kota besar. Karena menjamurnya pusat kebugaran yang ada di kota-kota besar, maka tidak heran apabila timbul persaingan yang cukup ketat. Salah satunya yaitu pusat kebugaran Lembah Fitness Centre Universitas Gajah Mada (UGM). Lembah Fitness Centre ini beralamatkan di gedung olahraga tennis indoor, taman Lembah UGM Yogyakarta.

Lembah Fitness Centre ini terbuka untuk umum dan tidak membeda-bedakan status ekonomi, karena semua golongan, baik pelajar, mahasiswa maupun masyarakat dapat menggunakan fasilitas yang ada. Selain itu, Lembah Fitness Centre berusaha untuk menyediakan fasilitas kegiatan olahraga bagi masyarakat berupa program latihan beban dan senam aerobik. Adapun program yang ditawarkan berupa: program pembentukan fisik atlet, penurunan berat badan, penambahan berat badan, kebugaran, pembentukan otot (body building), terapi dan rehabilitasi pasca cedera, personal trainer, dan berbagai jenis variasi senam aerobik. Di samping itu, Lembah Fitness Centre melayani tes kebugaran bagi atlet maupun masyarakat umum.

Lembah Fitness Centre UGM memiliki jumlah members yang cukup banyak. Disana terdapat members aktif dan tidak aktif. Anggota yang tergolong members aktif yaitu members yang sering berlatih dan rutin membayar iuran tiap bulannya, sedangkan members tidak aktif adalah members yang sudah tidak berlatih lagi dan tidak membayar iuran bulanan. Members yang 


\section{MEDIKORA, Vol. XVIII No. 1 April 2019 - 42}

Rina Yuniana, Ahmad Nasrulloh

tidak aktif berlatih kemungkinan disebabkan karena kualitas layanan yang kurang baik, manajemen yang kurang sesuai, instruktur yang kurang berpengalaman, maupun sebab-sebab lain. Hal ini mengakibatkan members tidak merasa puas dan malas untuk berlatih, sehingga menimbulkan penurunan jumlah members tiap bulannya.

Masing-masing pengusaha pengelola fitness centre harus mampu mengatur dan memanajemen klub kebugarannya dengan sebaik mungkin, menerapkan strategi pemasaran yang jitu, sehingga dapat menarik konsumen sebanyak-banyaknya dan dapat mempertahankan pangsa pasar dengan memperoleh keuntungan yang sebesar-besarnya. Demikian halnya di Lembah Fitness Centre UGM juga perlu melakukan pengelolaan dan menerapkan strategi pemasaran yang baik agar members dapat merasakan kepuasan. Oleh sebab itu, pada kesempatan ini peneliti mengadakan penelitian dengan judul "Tingkat Kepuasan Members terhadap Strategi Pemasaran di Lembah Fitness Centre UGM.

\section{Kepuasan Pelanggan}

Kotler (2002: 145) mengatakan bahwa kepuasan adalah perasaan senang atau kecewa yang berasal dari perbandingan antara kesannya terhadap kinerja atau hasil suatu produk dan harapanharapannya. Kepuasan merupakan fungsi dari kesan kinerja dan harapan. Jika kinerja di bawah harapan, pelanggan akan tidak puas, jika kinerja memenuhi harapan, pelanggan akan puas, dan jika kinerja melebihi harapan, pelanggan amat puas atau senang. Pelanggan yang merasa puas akan kembali membeli, dan akan memberitahu yang lain tentang produk yang digunakan. Menurut Irawan (2002: 3) kepuasan sebagai persepsi terhadap produk atau jasa yang telah memenuhi harapannya. Kepuasan pelanggan adalah hasil akumulasi dari konsumen atau pelanggan dalam menggunakan produk jasa. Tjiptono (2002: 146) mengatakan bahwa kepuasan pelanggan merupakan evaluasi purna beli dimana alternatif yang dipilih sekurang-kurangnya memberikan hasil (outcome) sama atau melampaui harapan pelanggan-pelanggannya.

Ada kesamaan di antara beberapa pengertian di atas, yakni menyangkut komponen kepuasan pelanggan meliputi harapan dan kinerja atau hasil yang dirasakan. Umumnya harapan pelanggan tentang apa yang akan diterima bila pelanggan tersebut membeli atau mengkonsumsi suatu produk berupa barang dan jasa, sedangkan kinerja yang dirasakan adalah persepsi pelanggan terhadap apa yang ia terima setelah mengkonsumsi suatu produk yang di beli. Jadi tingkat kepuasan pelanggan merupakan fungsi dari perbedaan antara kinerja yang dirasakan dengan harapan. Apabila kinerja sesuai dengan harapan, pelanggan akan puas. Pelanggan yang puas akan setia lebih lama, kurang sensitif terhadap harga dan memberi komentar yang baik terhadap perusahaan. Untuk menciptakan kepuasan pelanggan, perusahaan harus menciptakan dan mengelola suatu sistem untuk memperoleh pelanggan yang lebih banyak dan kemampuan untuk mempertahankan pelanggannya.

Lupiyoadi (2001: 158) mengatakan bahwa dalam menentukan kepuasan pelanggan, terdapat lima faktor utama yang harus diperhatikan oleh perusahaan, yaitu: a) Kualitas Produk, pelanggan akan merasa puas bila hasil evaluasi mereka menunjukkan bahwa produk yang mereka gunakan berkualitas; b) Kualitas Pelayanan, terutama untuk industri jasa, pelanggan akan merasa puas bila mereka mendapatkan pelayanan yang baik atau yang sesuai dengan yang diharapkan; c) Emosional, pelanggan akan merasa bangga dan mendapatkan keyakinan bahwa orang lain akan kagum terhadap dia bila menggunakan produk dengan merk tertentu yang cenderung mempunyai tingkat kepuasan yang lebih tinggi; d) Harga, produk yang mempunyai kualitas yang sama tetapi menetapkan harga yang relatif murah akan memberikan nilai yang lebih tinggi kepada pelanggannya; e) Biaya, pelanggan yang tidak perlu mengeluarkan biaya tambahan atau tidak 


\section{MEDIKORA, Vol. XVIII No. 1 April 2019 - 43}

Rina Yuniana, Ahmad Nasrulloh

perlu membuang waktu untuk mendapatkan suatu produk atau jasa cenderung puas terhadap produk atau jasa itu.

Pengukuran terhadap kepuasan pelanggan merupakan hal yang sangat penting bagi setiap usaha. Hal ini dikarenakan langkah tersebut dapat memberikan umpan balik dan masukan bagi keperluan pengembangan dan implementasi strategi peningkatan kepuasan pelanggan. Pada prinsipnya kepuasan pelanggan dapat diukur dengan berbagai macam metode. Alat-alat yang dapat digunakan setiap perusahaan untuk memantau dan mengukur kepuasan pelanggan beragam dari yang sederhana sampai yang canggih. Tjiptono (2002: 148-149) menyatakan bahwa metode yang paling banyak digunakan dalam pengukuran kepuasan pelanggan adalah metode survai. Melalui metode survai ini, perusahaan jasa akan memperoleh tanggapan dan umpan balik secara langsung dari pelanggan dan sekaligus juga memberikan tanda (signal) positif bahwa perusahaan menaruh perhatian terhadap para pelanggannya.

\section{Strategi Pemasaran}

Pada masa globalisasi sekarang ini pemasaran merupakan kegiatan yang memegang peranan penting dalam dunia usaha. Sebuah perusahaan dapat dikatakan sukses dalam persaingan bisnis, jika perusahaan tersebut mampu menganalisis kebutuhan konsumen dengan cermat, mendefinisikan peluang atau kesempatan dan menciptakan peluang pasar bagi konsumen yang belum terjangkau oleh pesaing serta mampu mengelola fungsi pemasaran dengan baik. Kata pemasaran berasal dari kata market dalam bahasa Inggris yang berarti pasar atau mekanisme yang mempertemukan permintaan dan penawaran. Pemasaran merupakan salah satu kegiatan pokok yang dilakukan oleh perusahaan untuk mempertahankan kelangsungan hidupnya. Banyak sekali pengertian pemasaran yang dikemukakan oleh para ahli meskipun berbeda-beda tetapi pada dasarnya adalah sama.

Perbedaan tersebut dikarenakan perbedaan sudut pandang. Untuk memperjelas pengertian pemasaran, maka dibawah ini dikemukakan beberapa pendapat dari para ahli, yaitu: Menurut American Marketing Association (AMA) pemasaran adalah pelaksanaan kegiatan perusahaan yang mengarahkan arus barang dan jasa dari produsen ke konsumen atau industri pemakai, (Swasta, 1984: 10). Menurut Kotler (2000: 9) pemasaran adalah suatu proses sosial yang didalamnya individu dan kelompok mendapatkan apa yang mereka inginkan dengan menciptakan, menawarkan, dan secara bebas mempertukarkan produk yang bernilai dengan orang lain. Pemasaran ini berarti mengelola pasar untuk menghasilkan pertukaran serta hubungan dengan menciptakan nilai dan memuaskan kebutuhan maupun keinginan. Nugroho (2000: 74) berpendapat bahwa pemasaran adalah cara pandang seluruh perusahaan barang/jasa dalam beradaptasi terhadap lingkungannya secara kreatif dan menguntungkan. Tugas pemasaran adalah memberi dan mendistribusikan kebutuhan-kebutuhan masyarakat yang menjadi peluang menguntungkan, agar produk tersebut dapat dikenal oleh masyarakat.

Pemasaran mencakup semua kegiatan perusahaan yang dimulai dengan mengidentifikasi kebutuhan konsumen yang perlu dipuaskan, menentukan produk yang hendak diproduksi, menentukan harga produk yang sesuai, menentukan cara-cara promosi yang tepat dengan biaya seefisien mungkin, dan menentukan penyaluran barang atau jasa yang akan dijual. Pemasaran yang baik (langgeng) sifatnya bukan hanya pemasaran dan transaksi saja, tetapi pemasaran yang berdasarkan pada hubungan. Hubungan yang baik akan membangun suatu hubungan jangka panjang serta saling percaya di antara kedua belah pihak.

Strategi pemasaran adalah bagian dari lingkungan serta terdiri atas beberapa rangsangan sosial, rangsangan tersebut adalah produk dan jasa, materi, promosi, tempat pertukaran, dan harga 
(Peter \& Olson, 1996: 23). Dilihat dari sudut pandang organisasi pemasaran, strategi pemasaran adalah suatu rencana yang didesain untuk mempengaruhi pertukaran dalam mencapai tujuan organisasi (Peter \& Olson, 1996: 10). Menurut Kotler dan Amstrong (2001: 71) strategi (bauran) pemasaran adalah seperangkat alat pemasaran taktis dan terkontrol yang dipadukan oleh perusahaan untuk menghasilkan respon/tanggapan yang diinginkan pasar sasaran (konsumen). Bauran pemasaran terdiri atas segala sesuatu yang dapat dilakukan perusahaan untuk mempengaruhi permintaan produknya. Strategi pemasaran yang dimaksud meliputi: product, place, promotion, dan price, yang sering dikenal dengan istilah 4P. Sedangkan Tjiptono (1995: 6) mengatakan bahwa strategi pemasaran merupakan alat fundamental yang direncanakan untuk mencapai tujuan perusahaan dengan mengembangkan keunggulan dalam bersaing secara berkesinambungan melalui pasar yang dimasuki/digunakan dalam proses pemasaran beserta program pemasaran yang digunakan untuk melayani pasar sasaran/konsumen. Strategi pemasaran merupakan bagian integral dari strategi bisnis yang memberikan arah pada semua fungsi manajemen dalam suatu organisasi.

Radiosunu (1986: 27-29) mengatakan bahwa strategi pemasaran terdiri atas empat konsep strategi. Konsep-konsep strategi tersebut adalah sebagai berikut: a) Segmentasi pasar. Tiap pasar terdiri atas bermacam-macam pembeli yang mempunyai kebutuhan, kebiasaan membeli, dan reaksi yang berbeda-beda. Perusahaan tidak mungkin dapat memenuhi kebutuhan semua pembeli, karena itu perusahaan harus mengelompokkan pasar yang bersifat heterogen tersebut ke dalam satu-satuan pasar yang bersifat homogeny; b) Marketing positioning. Perusahaan tidak mungkin dapat menguasai pasar keseluruhan. Prinsip pemasaran yang kedua adalah memilih pola spesifik pemusatan pasar yang akan memberikan kesempatan maksimum kepada perusahaan untuk mendapatkan kedudukan yang kuat, dengan kata lain perusahaan harus memilih segmen pasar yang dapat menghasilkan penjualan dan laba yang paling besar. c) Market entry strategy, adalah strategi memasuki segmen yang dijadikan sasaran penjualan. Memasuki sesuatu segmen pasar dapat dilakukan dengan cara membeli perusahaan lain, internal development, dan kerja sama dengan perusahaan lain; d) Marketing-mix strategy (strategi pemasaran) adalah kumpulan variabel yang dapat digunakan perusahaan untuk mempengaruhi tanggapan konsumen. Variabel yang dapat mempengaruhi pembeli adalah variabel-variabel yang berhubungan dengan produk, tempat, promosi, dan harga.

Dari berbagai macam konsep strategi pemasaran di atas, peneliti akan mengambil salah satu konsep yang berhubungan dengan penelitian ini, yaitu marketing-mix strategy (bauran strategi pemasaran) yang terdiri atas kumpulan variabel-variabel yang dapat mempengaruhi pembeli, yaitu variabel yang berhubungan dengan produk, tempat, promosi, dan harga, dijelaskan sebagai berikut; a) Faktor Produk. Menurut Kotler dan Amstrong (2001: 72) produk adalah kombinasi barang dan jasa yang ditawarkan oleh perusahaan kepada pasar sasaran. Dalam bidang fitness centre, produk ini berwujud jasa atau pelayanan yang diberikan untuk members; b) Faktor Harga. Harga adalah jumlah uang yang dibutuhkan untuk mendapatkan sejumlah kombinasi dari barang dan jasa serta pelayanannya (Swasta, 1984: 147). Menurut Kotler \& Amstrong (2001: 73) harga adalah sejumlah uang yang harus dibayar oleh pelanggan untuk memperoleh produk. Harga merupakan faktor yang penting dalam bisnis fitness centre, karena akan menentukan berhasil atau tidaknya bisnis tersebut; c) Faktor Promosi. Promosi adalah arus informasi satu arah yang dibuat untuk mengarahkan seseorang atau organisasi kepada tindakan yang menciptakan pertukaran dalam pemasaran (Swasta, 1984: 237). Menurut Kotler \& Amstrong (2001: 74) promosi adalah aktivitas mengkomunikasikan keunggulan produk serta membujuk pelanggan untuk membelinya. Promosi merupakan suatu sarana untuk menghubungkan antara penjualan dengan pembeli yang 
bertujuan untuk mempermudah sampainya suatu informasi dari produsen ke konsumen; d) Faktor Lokasi. Lokasi adalah tempat dimana seseorang dapat membeli barang atau jasa yang diinginkan (Peter \& Olson, 1996: 11). Menurut Kotler \& Amstrong (2001: 73) lokasi atau tempat meliputi aktivitas perusahaan agar produk mudah didapatkan konsumen.

\section{METODE}

\section{Populasi dan Sampel Penelitian}

Populasi yang digunakan dalam penelitian ini adalah members Lembah Fitness Centre UGM yang aktif mengikuti latihan beban, sebanyak 240 orang. Sampel penelitian yang diambil dalam penelitian ini yaitu dengan metode nonprobability sampling menggunakan teknik accidental sampling. Yang dimaksud dengan accidental sampling pada penelitian ini adalah members Lembah Fitness Centre UGM yang mengikuti latihan beban yang kebetulan ada atau dijumpai pada saat dilakukan pengumpulan data, yaitu sebanyak 120 orang.

\section{Instrumen Penelitian}

Instrumen yang digunakan adalah angket atau kuesioner. Angket tersebut diujicobakan terhadap 40 members Lembah Fitness Centre UGM. Hasil ujicoba menunjukkan dari 48 butir pernyataan gugur 3 butir, sahih 45 butir. Teknik untuk mengukur validitas menggunakan teknik korelasi product moment dari Karl Pearson dengan taraf signifikasi $5 \%$ atau $\alpha=0,05$. Butir pernyataan dikatakan valid apabila nilai korelasi dari product moment (rxy) lebih besar dari r-tabel. Nilai koefisien alpha (rtt) yang diperoleh sebesar 0,912 dengan status reliabel. Teknik analisis data penelitian menggunakan analisis deskriptif kuantitatif dengan persentase.

\section{HASIL DAN PEMBAHASAN}

Dari hasil penelitian yang telah dilakukan menunjukkan bahwa tingkat kepuasan members terhadap strategi pemasaran di Lembah Fitness Centre UGM termasuk dalam kategori memuaskan dengan jumlah persentase total $60,8 \%$. Adapun faktor-faktor yang mendukung adalah sebagai berikut:

Pertama, Harga (Price). Price masuk dalam kategori sangat memuaskan, yaitu dengan persentase $60 \%$. Hal ini dikarenakan bahwa biaya pendaftaran menjadi anggota serta iuran tiap bulannya sudah tergolong murah dan terjangkau sesuai dengan pendapatan mereka. Untuk menjadi anggota di Lembah Fitness Centre UGM tergolong sangat mudah dan tidak membeda-bedakan status maupun golongan, sehingga memiliki jumlah members yang banyak. Selain itu, Lembah Fitness Centre UGM juga memberikan berbagai program insidental maupun paket-paket diskon yang menguntungkan members. Paket diskon tersebut dapat berupa diskon biaya maupun diskon waktu. Adanya paket diskon yang menguntungkan tersebut dapat membuat members merasa senang dan tetap bertahan menjadi members, sehingga jumlahnya pun makin bertambah banyak;

Kedua, Promosi (Promotion). Promotion masuk dalam kategori memuaskan, yaitu dengan persentase $55 \%$. Hal ini dikarenakan Lembah Fitness Centre telah mempromosikan klub kebugarannya dengan baik, yaitu melalui berbagai media, seperti media masa berupa iklan di surat kabar, majalah, media elektronik seperti radio dan televisi lokal, expo atau pameran, leaflet atau selebaran, maupun pemasangan spanduk di berbagai tempat strategis di Yogyakarta baik di perempatan jalan maupun di sekitar kampus. Manajemen Lembah Fitness Centre UGM melakukan promosi tidak hanya berbentuk lisan maupun tulisan tetapi mereka juga melakukannya dengan membuat animasi atau gambar. Tujuan dari promosi tersebut yaitu untuk menimbulkan daya tarik 


\section{MEDIKORA, Vol. XVIII No. 1 April 2019 - 46}

Rina Yuniana, Ahmad Nasrulloh

konsumen agar dapat bergabung atau mengikuti latihan di Lembah Fitness Centre UGM, sehingga klub kebugaran tersebut diharapkan memiliki jumlah members yang banyak.

Meskipun demikian, hasil yang telah diperoleh tersebut belum sepenuhnya maksimal, karena faktor promosi ini hanya masuk ke dalam kategori memuaskan. Hal tersebut harus ditingkatkan agar faktor ini dapat masuk dalam kategori sangat memuaskan. Salah satu hal yang menyebabkan kurang maksimalnya promosi yang dilakukan manajemen Lembah Fitness Centre UGM yaitu promosi atau publikasi yang dilakukan dari kampus ke kampus kurang maksimal, karena members di Lembah Fitness Centre UGM yang tergolong mahasiswa kebanyakan hanya berasal dari Universitas Gajah Mada (UGM), sedangkan mahasiswa di luar universitas tersebut masih jarang sekali bahkan hampir tidak ada.

Ketiga, Tempat (Place). Place masuk dalam kategori memuaskan, yaitu dengan persentase 49,2 \%. Hal ini dikarenakan Lembah Fitness Centre UGM memiliki fasilitas yang sangat lengkap. Lokasi atau tempat latihannya strategis dan mudah dijangkau oleh kendaraan pribadi maupun umum, serta berada di lingkungan sekitar kampus, sehingga menjadi suatu daya tarik tersendiri sebagai tempat untuk berolahraga. Ruang latihan di Lembah Fitness Centre UGM luas dan menyenangkan, dilengkapi dengan ventilasi yang memadai, sehingga sirkulasi udara di tempat latihan lancar dan tidak pengap. Seluruh dinding di ruang latihan dilengkapi dengan cermin. Cermin tersebut sangat membantu sekali apabila members sedang berlatih, yaitu ketika melakukan suatu gerakan, members dapat melihat secara langsung apakah gerakannya sudah benar dan sesuai dengan tujuan latihan atau masih salah. Apabila masih salah, maka tujuan latihan tidak akan tercapai dan members tidak akan merasakan hasil yang diinginkan. Selain itu, peralatan yang digunakan untuk berlatih semuanya dalam kondisi baik dan layak pakai serta menjamin keselamatan pengguna atau members.

Lembah Fitness Centre UGM juga memiliki fasilitas ruang ganti dan kamar mandi yang bersih dan terawat. Setiap members yang akan menggunakan fasilitas ruang ganti atau kamar mandi harus sesuai dengan jenis kelaminnya masing-masing. Di Lembah Fitness Centre UGM juga menyediakan loker yang digunakan sebagai tempat untuk menyimpan barang milik members. Loker-loker tersebut jumlahnya sangat banyak dan kondisinya pun dalam keadaan baik, sehingga members yang berlatih tidak akan merasa khawatir atau takut kehilangan barang yang mereka bawa. Di samping fasilitas di atas, Lembah Fitness Centre UGM juga menyediakan mushola atau tempat beribadah yang berfungsi untuk mempermudah members dalam melaksanakan ibadahnya. Ruang tamu, ruang resepsionis, ruang instruktur, ataupun ruang konsultasi pun tersusun rapih dan teratur, sehingga akan mempermudah dalam melayani members, baik members baru maupun members lama.

Meskipun demikian, hasil yang diperoleh belum sepenuhnya maksimal karena faktor place ini hanya masuk kedalam kategori memuaskan. Hal tersebut harus ditingkatkan agar faktor ini dapat masuk ke dalam kategori sangat memuaskan. Salah satu hal yang menyebabkan place kurang maksimal yaitu tempat parkir kendaraan yang berada di Lembah Fitness Centre UGM harus membayar, sehingga banyak members yang merasa kurang nyaman karena ketika mereka hendak latihan, mereka harus mengeluarkan biaya lagi. Selain itu, ruangan yang digunakan sebagai tempat untuk berlatih tidak dilengkapi AC maupun kipas angin sehingga apabila ruangan padat oleh members yang berlatih, maka ruangan tersebut akan terasa pengap dan tidak nyaman untuk berlatih atau berolahraga.

Keempat, Produk atau jasa (Product). Product masuk dalam kategori memuaskan, yaitu dengan persentase 55,8 \%. Hal ini dikarenakan Lembah Fitness Centre UGM memiliki manajemen dan staf yang cukup bagus. Ditinjau dari jumlah karyawan maupun staf sudah memadai, baik 
instruktur, resepsionis, maupun konsultan kebugaran. Dalam penampilan pertama, resepsionislah yang menerima members maupun calon members yang akan mendaftar maupun yang akan berlatih. Semua administrasi yang berhubungan dengan klub kebugaran ditangani langsung oleh resepsionis. Dalam melayani members, resepsionis selalu bersikap ramah dan sopan serta mampu menjelaskan semua yang berhubungan tentang klub kebugaran tersebut, baik menawarkan program-program latihan yang ada maupun menjelaskan persyaratan menjadi anggota.

Lembah Fitness Centre UGM memiliki instruktur yang cukup dan berkualitas, sehingga mampu mencukupi dalam melayani members. Instruktur di Lembah Fitness Centre UGM telah mendapatkan bekal dan pengetahuan yang memadai tentang kebugaran. Semua program latihan yang ditawarkan kepada members mampu dikuasai dan dijalankan dengan baik. Setiap members yang berlatih, instruktur selalu mengawasi atau mengontrol. Bagi members mau berlatih, instruktur selalu mendampingi dan memberikan pengarahan sampai members tersebut dapat mandiri dan mampu melakukan latihan sendiri. Bagi setiap members yang memiliki keluhan dalam melakukan latihan maupun yang berhubungan dengan program yang dijalankan, maka keluhan tersebut dapat disampaikan langsung pada instruktur atau konsultan kebugaran.

Setiap satu bulan sekali instruktur akan mengontrol perkembangan setiap members yang berlatih. Apakah ada perkembangan atau hasil yang diperoleh dari latihan atau tidak, yaitu dengan melakukan pengukuran ulang. Apabila pengukuran tersebut sesuai dengan yang diharapkan atau memberikan hasil yang memuaskan pada members, maka program latihan yang dijalankan sudah berhasil dan sesuai dengan tujuan yang diinginkan. Di samping itu, Lembah Fitness Centre UGM memiliki jadwal buka dan tutup yang sesuai atau tepat waktu, yaitu dari pukul 05.30 WIB sampai dengan pukul $21.00 \mathrm{WIB}$, sehingga members memiliki banyak kesempatan untuk berlatih, karena waktu yang disediakan cukup lama. Lembah Fitness Centre UGM juga memberikan kebebasan kepada members yang ingin berlatih beberapa kali sehari, baik pagi, siang, maupun malam. Di samping itu, Lembah Fitness Centre UGM buka setiap hari dan libur hanya saat libur nasional, sehingga members dapat berlatih kapan pun mereka mau.

Meskipun demikian, hasil yang telah diperoleh tersebut belum sepenuhnya maksimal, karena faktor product ini hanya masuk kedalam kategori memuaskan. Hal tersebut harus ditingkatkan, agar faktor ini dapat masuk kedalam kategori sangat memuaskan. Ada beberapa hal yang menyebabkan product kurang maksimal, yaitu adanya instruktur yang masih berstatus mahasiswa, sehingga kadang-kadang tidak masuk atau absen dari tugasnya karena alasan kuliah. Selain itu, layanan pemeriksaan kesehatan dan kebugaran yang ditawarkan jarang dilaksanakan, sehingga program latihan kurang tercapai.

\section{SIMPULAN}

Berdasarkan analisis data dan pembahasan dapat disimpulkan bahwa secara umum tingkat kepuasan member terhadap strategi pemasaran di Lembah Fitness Centre UGM masuk dalam kategori memuaskan. Adapun secara rinci tingkat kepuasan members terhadap strategi pemasaran di Lembah Fitness Centre UGM, yaitu melalui faktor-faktor berikut: (1) Price masuk dalam kategori sangat memuaskan, (2) Promotion masuk dalam kategori memuaskan, (3) Place masuk dalam kategori memuaskan, (4) Product masuk dalam kategori memuaskan.

\section{DAFTAR PUSTAKA}

Nugroho, A. (2000). “Pemasaran Jasa Bidang Olahraga.” Majalah Olahraga. (Volume VI). Hlm. 73-86.

Swasta, B. (1984). Azas-azas Manajemen Modern. Yogyakarta: Liberty. 
Swasta, B. (1986). Azas-azas Marketing. Yogyakarta: Liberty.

Irianto, D, P. (2004). Pedoman Praktis Berolahraga. Yogyakarta: Andi Offset.

Tjiptono, F. (1995). Strategi Pemasaran. Ed. 2. Cet. 3. Yogyakarta: Andi Offset.

Tjiptono, F. (2002). Manajemen Jasa. Ed. 2. Cet. 3. Yogyakarta: Andi Offset.

Irawan., H. (2002). 10 Prinsip Kepuasan Pelanggan. Jakarta: PT. Elex Media Komputindo.

Peter, J.P. \& Olson, J.C. (1996). Perilaku Konsumen dan Strategi Pemasaran. (Damos Sihombing. dan Yati Sumiharti. Terjemahan). Jakarta: Erlangga.

Kotler \& Amstrong. (2001). Prinsip-prinsip Pemasaran. (Damos Sihombing. dan Wisnu Candra K. Terjemahan). Jakarta: Erlangga.

Philip, Kotler et. al. (2000). Manajemen Pemasaran: Perspektif Asia. Ed. 1. (Fandy Tjiptono. Terjemahan). Yogyakarta: Andi Offset.

Radiosunu. (1986). Manajemen Pemasaran suatu Pendekatan Analisis. Yogyakarta: BPFE.

Lupiyoadi, R. (2001). Manajemen Pemasaran Jasa: Teori dan Praktik. Jakarta: Salemba Empat. 